\title{
Ethnic density and prevalence of psychiatric morbidity among patients with hiv infection in Sokoto, Nigeria-A control study
}

\author{
Mufutau A. Yunusa*, Ayodele Obembe \\ Department of Psychiatry, Usmanu Danfodiyo University, Sokoto, Nigeria \\ Email: *yunusamufutau@yahoo.com
}

Received 4 September 2012; revised 2 October 2012; accepted 10 October 2012

\begin{abstract}
Background: Previous studies among people living with HIV infection suggested that prevalence of psychiatric morbidity was high. In addition, among nonHIV infected patients, ethnic density influence the prevalence. The present study was aimed to determine the prevalence and effects of ethnic density on psychiatric morbidity among these patients in Sokoto, Nigeria. Methods: This prospective cross-sectional study was conducted among patients who had been diagnosed with HIV infection in a teaching hospital in Sokoto. Questionnaire relating to sociodemographic variables and psychiatric morbidity were administered to the patients. Data obtained were analyzed using SPSS version 16.0 while test for significance was set at $P<0.05$. Result: The mean age of the patient was $32 \pm 9$ years (range $=12-63$ ), male being older than the female. Of the patients, $71 \%$ were married while and about two third were of Islamic religion. Twenty seven percent had no formal education and were mainly Hausa/Fulani ethnicity. Seven percent of the patients had definite depression while $8 \%$ had definite anxiety. When the subjects were dichotomized to Hausa/Fulani and others, they were similar with regard to age and gender $\left(\chi^{2}=4.43 ; P=\right.$ 0.49 and $\chi^{2}=0.22 ; \mathrm{P}=0.64$ respectively). Across the ethnicity (Hausa/Fulani and others), the subjects differ significantly with regard to religion $\left(\alpha^{2}=0.68 ; \mathbf{P}=\right.$ 0.00), marital status $\left(\chi^{2}=15.05 ; P=0.00\right)$, education $\left.\alpha^{2}=30.56 ; \mathbf{P}=0.00\right)$ and employment status $\alpha^{2}=$ 9.81; $P=0.01)$. The Hausa/Fulani ethnic group had less psychiatric morbidity. In addition, marital status had significant pathoplastic effect on depression across ethnicity $\left(\chi^{2}=0.42 ; P=0.02\right)$. Conclusion: Ethnic density was associated with decrease prevalence of common mental disorder among patients with HIV infection. Environmental manipulation may play a role in the management of this patient.
\end{abstract}

*Corresponding author.
Keywords: Ethnicity; HIV; Morbidity; Prevalence; Psychiatric

\section{INTRODUCTION}

The prevalence of anxiety and depression among HIV patients is high, however varied [1-3]. In one report, nearly half of the patients with HIV infection were reported to have psychiatric morbidity [4]. However in another study a smaller percentage was reported [5]. A prevalence of $22 \%$ to $32 \%$ [6,7] which was 2 to 3 times higher than the prevalence of psychiatric disorders in general community population has also been reported. However in a longitudinal study of Maj et al. [5], lower prevalence of $9 \%$ of major depression and $2 \%$ of anxiety disorder were reported after 6-months follow up [8]. In south west Nigeria, prevalence of depression among patients with HIV infection was 59.1\% [9].

The effects of psychiatric morbidity on HIV infection underscored the need to study psychiatric morbidity closely among the patients and identify the predisposing factors. Depression and anxiety disorder were reported to speed progression of the disease $[10,11]$. In addition, depression has negative effect on course and outcome of HIV infection [12] and substantially impact on quality of life of patients while anxiety has negative consequence on social role and mental functioning [13].

Ethnic density is one factor that had been reported to influence distribution of psychiatric morbidity and in particular beneficial pathoplastic effects on psychiatric morbidity. It is defined as the relative size of a given ethnic group in a multi ethnic neighbourhood [14]. In one report Rabkin [14] reported on the hazards of ethnic minority status on psychiatric hospitalization. They showed that the ethnic density had protective association on suicide and self harm as well as on psychosis [15]. In a large community study in England and Wales [16], 5167 ethnic minority and 2867 white were studied. The protective effects of ethnic density on psychiatric 
morbidity were also observed.

This study was aimed at determining the influence of ethnic density on prevalence of anxiety and depression among Hausa/Fulani ethnic group with HIV infection in Sokoto.

\section{METHODS}

\subsection{Study Design and Location}

This was part of a large study. Detail on methodology was reported in earlier report [17]. This cross sectional study was carried out among patients who were diagnosed of HIV infection at the VCT [voluntary counseling and testing] centre of Usmanu Danfodiyo University Teaching Hospital, Sokoto, North Western Nigeria. The study included 167 consecutive adult patients who were attending their routine clinic. Both symptomatic and non symptomatic patients were included.

\subsection{Data Collection}

Variables relating to socio demographic profile and substance use were obtained through the use of questionnaire designed by the authors while psychiatric morbidity was assessed using Hospital Anxiety and Depression Scale (HADS) [18].

\subsection{Sociodemographic Questionnaire}

Sociodemographic questionnaire was designed by the authors to enquire about basic epidemiological variables including age, sex, occupation and religion.

\subsection{Hospital Anxiety and Depression Scale}

This 14-item questionnaire was developed by Zigmond and Snaith [18] to determine the presence of anxiety and depression among patients with medical conditions. Using Likert scoring scale, score range is $0-21$ for each of the condition. While patients with score of $0-7$ are considered as non cases, those that scored 8 - 10 and 11 and above were considered as borderline and definite cases for anxiety or depression respectively. It has been validated and used in previous studies in Nigeria. Abiodun [19] reported from a Nigerian community that the sensitivity for the anxiety subscale ranged from $85.0 \%$ in the medical and surgical wards to $92.9 \%$ in the ante-natal clinic, while sensitivity for the depression sub-scale ranged from $89.5 \%$ in the community sample to $92.1 \%$ in the gynaecology clinic. The specificity for the anxiety sub-scale ranged from $86.5 \%$ in the gynaecology clinic to $90.6 \%$ in the community sample, while specificity for the depression sub-scale ranged from $86.6 \%$ in the medical and surgical wards to $91.1 \%$ in the ante-natal clinic and community sample. Misclassification rates ranged from $9.9 \%$ in the community sample to $13.2 \%$ in the medical and surgical wards. Relative operating characteristics (ROC) analyses showed the HADS and the GHQ 12 to be quite similar in ability to discriminate between cases and non cases. Fatoye et al. [20] used HADS in the study of prevalence of anxiety and depression in patients with epilepsy in a Nigerian community. A study had shown that depression subscale is useful to determine the presence of clinical depression than beck depression inventory (Jose, et al.) [21].

\subsection{Analysis}

For the purpose of analysis anxiety and depressive symptoms was made for any patients that cross the threshold of 7 on HADS in the scoring thereby comprising of borderline and definite anxiety and depression, while those with definite anxiety and depression were treated separately in other analysis. In addition age of onset of illness was calculated hypothetically by subtracting age at time of the study from the period since the illness was diagnosed.

Data was analyzed descriptively using SPSS for windows version 16.0. Cases with missing data for the HADS were excluded.

\section{RESULT}

A total of one hundred and sixty seven consecutive adult patients were recruited for the study. Of these patients, 8 (4.8\%) did not fill HADS questionnaire completely to be incorporated into the analysis giving response rate of 95.2\%. Eighty six (55.8\%) of them were Hausa/Fulani ethnic group while 68 (44.2\%) others included Yoruba, Igbo among others (Figure 1). The mean age of the patients was $34.52 \pm 8.93$. One hundred and fourteen (71.7\%) were married, 25 (15.7\%) were widowed, 8 (5\%) were divorced and 11 (8.9\%) were never married. Also, ninety seven (61\%) were Muslims and 60 (37.7\%) were Christians. About a quarter of the patients had no formal education while about 30\% had post secondary education. Of the subjects, fifteen $(9.5 \%)$ were found to have borderline depression while 12 (7.6\%) had definite depression. In addition, 10 (6.3\%) were found to have anxiety while 14 (8.8\%) had definite anxiety (Tables 1 and 2). Mean score for the patients on HADS-anxiety, subscale was $3.62 \pm 4.03$ and HADS (depression) was $4.33 \pm 3.81$. The mean HADS score for anxiety and depression among patients who had definite anxiety and depression were $13.00 \pm 2.63$ and $13.17 \pm 2.76$ respectively. Table 3 showed the sociodemographic of the Hausa/Fulani ethnic group against the other ethnic group. With regard to age and gender, the two groups were similar $\left(\chi^{2}=4.43 ; \mathrm{P}=0.49\right)$ and $\left(\chi^{2}=0.22 ; \mathrm{P}=0.64\right)$. The groups differed significantly across religion $\left(\chi^{2}=\right.$ $0.68 ; \mathrm{P}=0.00$ ) and marital status with more of the Hausa/Fulani ethnic group being widow $\left(\chi^{2}=15.05\right.$; $\mathrm{P}=$ $0.00)$. In addition more of the Hausa ethnic group had no 


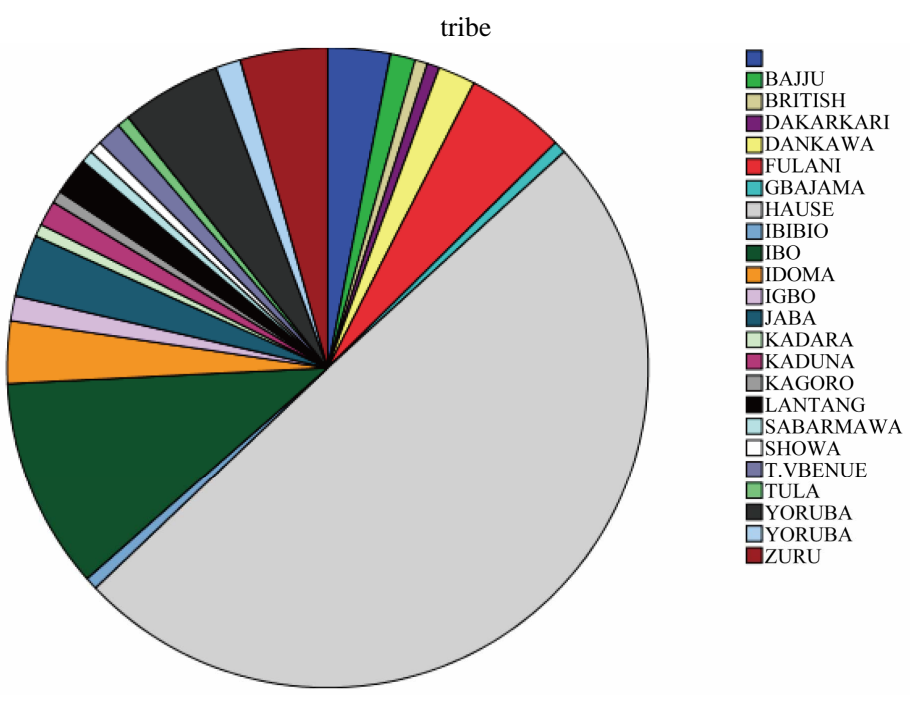

Figure 1. Ethnicity.

Table 1. Sociodemographic characteristics and prevalence of psychiatric morbidity.

\begin{tabular}{|c|c|c|}
\hline Characteristics & Number & $\%$ \\
\hline \multicolumn{3}{|l|}{ AGE } \\
\hline$<20$ & 2 & 1.3 \\
\hline $20-29$ & 47 & 29.9 \\
\hline $30-39$ & 66 & 42.0 \\
\hline $40-49$ & 33 & 21.0 \\
\hline $50-59$ & 8 & 5.1 \\
\hline $60-60+$ & 1 & 0.6 \\
\hline Total & 157 & 100.0 \\
\hline \multicolumn{3}{|l|}{ Gender } \\
\hline Male & 48 & 30.2 \\
\hline Female & 111 & 69.8 \\
\hline Total & 159 & 100.0 \\
\hline \multicolumn{3}{|l|}{ Religion } \\
\hline Islam & 97 & 61.8 \\
\hline Christianity & 60 & 38.2 \\
\hline Total & 157 & 100.0 \\
\hline \multicolumn{3}{|l|}{ Marital status } \\
\hline Never married & 11 & 6.9 \\
\hline Married & 114 & 71.7 \\
\hline Separated & 1 & 0.6 \\
\hline Divorced & 8 & 5.0 \\
\hline Widow & 25 & 15.7 \\
\hline Total & 159 & 100.0 \\
\hline \multicolumn{3}{|l|}{ Education } \\
\hline No formal education & 44 & 27.8 \\
\hline Primary & 19 & 12.0 \\
\hline Secondary & 47 & 29.7 \\
\hline Post secondary & 48 & 30.4 \\
\hline Total & 158 & 99.9 \\
\hline
\end{tabular}

Table 2. Sociodemographic characteristics and prevalence of psychiatric morbidity (cont'd).

\begin{tabular}{lcc}
\hline & Number & \% \\
\hline Tribe & 86 & \\
Hausa / Fulani & 68 & 55.8 \\
Others & $\mathbf{1 5 4}$ & 44.2 \\
Total & & $\mathbf{1 0 0 . 0}$ \\
Depression & 130 & \\
Normal & 15 & 82.3 \\
Borderline & 12 & 9.5 \\
Definite & $\mathbf{1 5 8}$ & 7.6 \\
Total & & $\mathbf{9 9 . 4}$ \\
Anxiety & 134 & \\
Normal & 10 & 84.3 \\
Borderline & 14 & 6.3 \\
Definite & $\mathbf{1 5 8}$ & 8.8 \\
Total & & $\mathbf{9 9 . 4}$ \\
\hline
\end{tabular}

formal education compared to the other ethnic group $\left(\chi^{2}=\right.$ 30.56; $\mathrm{P}=0.00$ ) and similarly, more of the Hausa ethnic group were unemployed $\left(\chi^{2}=9.81 ; \mathrm{P}=0.01\right)$. As shown in Table 4, prevalence of definite depression and anxiety disorder were higher than that of the Hausa/Fulani ethnic group.

In Table 5, sociodemographic characteristics of the subjects were cross tabulated against psychiatric morbiddity. Subjects who were of age group 20 - 29 years were more associated with borderline psychiatric morbidity and those who were divorced. In addition, sociodemo-graphic characteristics of each of the 2 groups (Hausa/Fulani and others) were examined for the distribution of psychiatric morbidity (Tables 6 and 7). Across both groups, being 
Table 3. Sociodemographic characteristics across ethnicity of patients.

\begin{tabular}{|c|c|c|c|c|}
\hline Characteristics & Hausa/Fulani No. (\%) & Others No. (\%) & $\chi^{2}$ & P-value \\
\hline \multicolumn{5}{|l|}{ Age } \\
\hline$<20$ & $1(1.2)$ & $1(1.5)$ & 4.43 & 0.49 \\
\hline $20-29$ & $22(25.9)$ & $24(35.8)$ & & \\
\hline $30-39$ & $36(42.4)$ & $28(41.8)$ & & \\
\hline $40-49$ & $21(24.7)$ & $11(16.4)$ & & \\
\hline $50-59$ & $5(5.9)$ & $2(3.0)$ & & \\
\hline $60-60+$ & $0(0.0)$ & $1(1.5)$ & & \\
\hline Total & $85(100)$ & $67(100)$ & & \\
\hline \multicolumn{5}{|l|}{ Gender } \\
\hline Male & 27 (31.4) & $19(27.1)$ & 0.22 & 0.64 \\
\hline Female & $59(68.6)$ & 49 (72.1) & & \\
\hline Total & $86(100.0)$ & $68(100.0)$ & & \\
\hline \multicolumn{5}{|l|}{ Religion } \\
\hline Islam & 77 (91.7) & $17(25.0)$ & 0.68 & 0.00 \\
\hline Christianity & $7(8.3)$ & $51(75.0)$ & & \\
\hline Total & $84(100.0)$ & $68(100.0)$ & & \\
\hline \multicolumn{5}{|l|}{ Marital status } \\
\hline Never married & $2(2.3)$ & $9(13.2)$ & 15.05 & 0.00 \\
\hline Married & 57 (66.3) & $52(76.5)$ & & \\
\hline Separated & $1(1.2)$ & $0(0.0)$ & & \\
\hline Divorced & $7(8.1)$ & $1(1.5)$ & & \\
\hline Widow & $19(22.1)$ & $6(8.8)$ & & \\
\hline Total & $86(100.0)$ & $68(100.0)$ & & \\
\hline \multicolumn{5}{|l|}{ Education } \\
\hline No formal education & 39 (45.9) & $4(5.9)$ & 30.56 & 0.00 \\
\hline Primary & $9(10.6)$ & $10(14.7)$ & & \\
\hline Secondary & $17(20.0)$ & $28(41.2)$ & & \\
\hline Tertiary & $20(23.5)$ & $26(38.3)$ & & \\
\hline Total & $85(100.0)$ & $68(100.0)$ & & \\
\hline \multicolumn{5}{|l|}{ Employment status } \\
\hline Employed & 31 (36.9) & $40(62.5)$ & 9.81 & 0.01 \\
\hline Unemployed & 49 (58.3) & 23 (35.9) & & \\
\hline
\end{tabular}

Table 4. Distribution of psychiatric morbidity and ethnicity.

\begin{tabular}{|c|c|c|c|c|}
\hline CHARACTERISTICS & HAUSA/FULANI No. (\%) & OTHERS NO. (\%) & $\chi^{2}$ & P-Value \\
\hline \multicolumn{5}{|l|}{ Depression } \\
\hline Normal & $71(83.5)$ & $56(82.4)$ & 1.50 & 0.68 \\
\hline Borderline & $9(10.6)$ & $6(8.8)$ & & \\
\hline Definite & $5(5.9)$ & $5(7.4)$ & & \\
\hline TOTAL & $85(100.0)$ & $68(100.0)$ & & \\
\hline \multicolumn{5}{|l|}{ Anxiety } \\
\hline Normal & $74(86.0)$ & $56(82.4)$ & 1.89 & 0.59 \\
\hline Borderline & $6(7.0)$ & $4(5.9)$ & & \\
\hline Definite & $6(7.0)$ & $7(10.3)$ & & \\
\hline TOTAL & $86(100.0)$ & 67 (99.6) & & \\
\hline
\end{tabular}


Table 5. Sociodemographic characteristics and distribution of psychiatric morbidity among the patients.

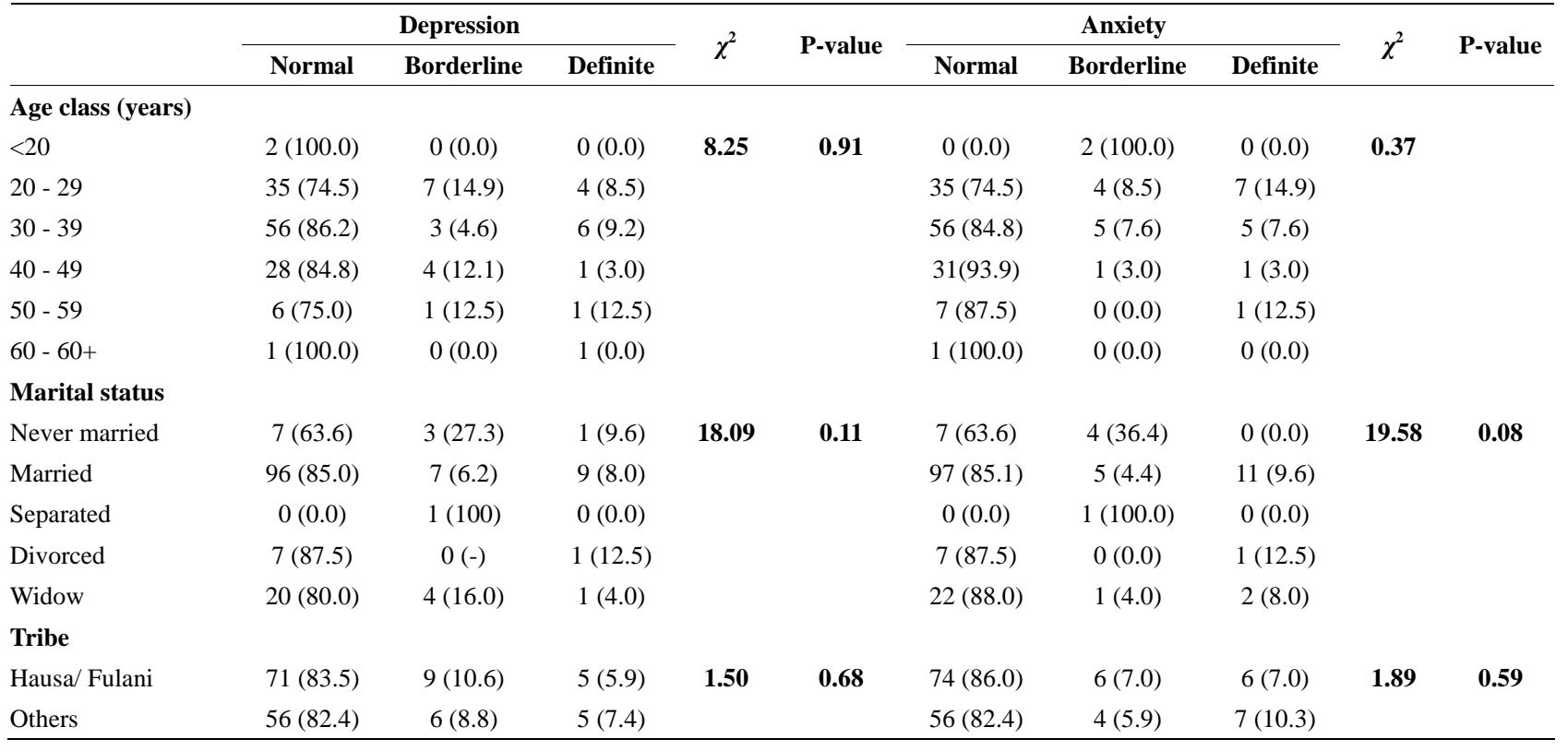

Table 6. Characteristics, prevalence of definite depression among the patients.

\begin{tabular}{|c|c|c|c|c|c|c|}
\hline & $\begin{array}{l}\text { Hausa/Fulani ethnic group } \\
\text { Definite depression }\end{array}$ & $\chi^{2}$ & P-value & $\begin{array}{l}\text { Other ethnic group } \\
\text { Definite depression }\end{array}$ & $\chi^{2}$ & P-value \\
\hline \multicolumn{7}{|l|}{ Age } \\
\hline$<20$ & $0(0.0)$ & 0.29 & 0.49 & $0(0.0)$ & 0.41 & 0.55 \\
\hline $20-29$ & $0(0.0)$ & & & $4(16.7)$ & & \\
\hline $30-39$ & $4(11.4)$ & & & $1(3.6)$ & & \\
\hline $40-49$ & $0(0.0)$ & & & $0(0.0)$ & & \\
\hline $50-59$ & $1(20.0)$ & & & $0(0.0)$ & & \\
\hline \multicolumn{7}{|l|}{$60-60+$} \\
\hline \multicolumn{7}{|l|}{ Total } \\
\hline \multicolumn{7}{|l|}{ Gender } \\
\hline Male & $1(3.7)$ & 0.11 & 0.60 & $0(0.0)$ & 0.19 & 0.46 \\
\hline Female & $4(6.9)$ & & & $5(10.2)$ & & \\
\hline \multicolumn{7}{|l|}{ Total } \\
\hline \multicolumn{7}{|l|}{ Religion } \\
\hline Islam & $5(6.6)$ & 0.08 & 0.8 & $2(11.8)$ & 0.13 & 0.76 \\
\hline Christianity & $0(0.0)$ & & & $3(5.9)$ & & \\
\hline \multicolumn{7}{|l|}{ Total } \\
\hline \multicolumn{7}{|l|}{ Marital status } \\
\hline Never married & $1(50.0)$ & 0.42 & 0.02 & $0(0.0)$ & 0.36 & 0.32 \\
\hline Married & $3(5.4)$ & & & $4(7.7)$ & & \\
\hline Separated & $0(0.0)$ & & & $0(0.0)$ & & \\
\hline Divorced & $1(14.3)$ & & & $0(0.0)$ & & \\
\hline Widow & $0(0.0)$ & & & $1(16.7)$ & & \\
\hline \multicolumn{7}{|l|}{ Total } \\
\hline \multicolumn{7}{|l|}{ Education } \\
\hline No formal education & $1(2.6)$ & 0.33 & 0.26 & $1(25.0)$ & 0.31 & 0.84 \\
\hline Primary & $2(22.2)$ & & & $1(10.0)$ & & \\
\hline Secondary & $2(11.8)$ & & & $1(3.6)$ & & \\
\hline Tertiary & $0(0.0)$ & & & $2(10.0)$ & & \\
\hline Total & & & & & & \\
\hline
\end{tabular}


Table 7. Characteristics, prevalence of anxiety among the patients.

\begin{tabular}{|c|c|c|c|c|c|c|}
\hline & Hausa/Fulani & P-value & $\chi^{2}$ & Others & P-value & $\chi^{2}$ \\
\hline \multicolumn{7}{|l|}{ Age } \\
\hline$<20$ & $0(0.0)$ & 0.30 & 0.39 & $0(0.0)$ & 0.35 & 0.87 \\
\hline $20-29$ & $3(13.6)$ & & & $4(16.7)$ & & \\
\hline $30-39$ & $1(2.8)$ & & & $3(10.7)$ & & \\
\hline $40-49$ & $1(4.8)$ & & & $0(0.0)$ & & \\
\hline $50-59$ & $1(20.0)$ & & & $0(0.0)$ & & \\
\hline \multicolumn{7}{|l|}{$60-60+$} \\
\hline \multicolumn{7}{|l|}{ Total } \\
\hline \multicolumn{7}{|l|}{ Gender } \\
\hline Male & $2(7.4)$ & 0.87 & 0.72 & $1(5.3)$ & 0.17 & 0.57 \\
\hline Female & $4(6.8)$ & & & $6(12.2)$ & & \\
\hline \multicolumn{7}{|l|}{ Total } \\
\hline \multicolumn{7}{|l|}{ Religion } \\
\hline Islam & $5(6.5)$ & & & $2(11.8)$ & 0.12 & 0.53 \\
\hline Christianity & $1(14.3)$ & & & $5(9.8)$ & 0.16 & 0.61 \\
\hline \multicolumn{7}{|l|}{ Total } \\
\hline \multicolumn{7}{|l|}{ Marital status } \\
\hline Never married & $0(0.0)$ & 0.28 & 0.52 & $0(0.0)$ & 0.43 & 0.08 \\
\hline Married & $4(7.0)$ & & & $6(11.5)$ & & \\
\hline Separated & $0(0.0)$ & & & $0(0.0)$ & & \\
\hline Divorced & $1(14.3)$ & & & $0(0.0)$ & & \\
\hline Widow & $1(5.3)$ & & & $1(16.7)$ & & \\
\hline \multicolumn{7}{|l|}{ Total } \\
\hline \multicolumn{7}{|l|}{ Education } \\
\hline No formal education & $1(2.6)$ & & & $1(25.0)$ & & \\
\hline Primary & $1(11.1)$ & & & $2(20.0)$ & & \\
\hline Secondary & $1(5.9)$ & & & $1(3.6)$ & & \\
\hline Tertiary & $2(10.0)$ & & & $3(11.5)$ & & \\
\hline \multicolumn{7}{|l|}{ Total } \\
\hline \multicolumn{7}{|l|}{ Employment status } \\
\hline Employed & $2(6.5)$ & 0.18 & 0.56 & $5(12.5)$ & 0.18 & 0.90 \\
\hline Unemployed & $4(8.2)$ & & & $2(8.7)$ & & \\
\hline
\end{tabular}

married and having higher education were associated with lower prevalence of psychiatric morbidity.

\section{DISCUSSION}

This study set out to determine the prevalence of psychiatric morbidity among patients with HIV infection who attended outpatient clinic of a tertiary hospital in Sokoto, Nigeria. In addition, to determine the impact of ethnic density on prevalence of psychiatric morbidity among the patients.

The subjects were mainly young and sexually active age group with about one third being married. More than two third of the patients were not gainfully employed, over half of them were married while another one third were widowed. In this culture, women often remarried soon after bereavement or divorce. This could be of interest in the study of HIV disease transmission.

Anxiety and depressive symptoms were present in $17.1 \%$ and $15.1 \%$ of the patients respectively while definite anxiety and depression were present in $8.8 \%$ and $7.5 \%$ respectively. We observed that the following were significantly associated with high prevalence of anxiety and depression namely: Young age group ( $<20$ years), female gender, tertiary education, being employed and 
being with the illness for greater than 3 years. Also, depressive symptom was more frequently associated with age group $<20$ years, female gender, and being with the illness for duration more than 5 years. Definite depression was found to be common among those who were of young age, female gender, with no formal education.

The prevalence of mood disorder in present study was consistent with previous studies among HIV infected patients. Grant et al. [22] reported prevalence of mood disorders in US population to be $9.21 \%$ while that of anxiety disorder was $11.08 \%$. This was also consistent with findings in a Kenya [5] and Tanzania [23] study. However other studies reported higher prevalence. Chandra et al. [24] reported prevalence of $40 \%$ of depression and $36 \%$ of anxiety among patients who attended tertiary centre in India using HADS. In Ethiopia, using Kassler [25] scale prevalence of common mental disorders among patients with HIV infection was $46.7 \%$ which was higher than findings in our study. The differences may be associated to sample size, socioculture and duration of illness. For instance in their study patients were recruited within 4 - 6 weeks of revelation of HIV status unlike our study with varied duration of illness from 2 weeks to 9 years. A previous study in Nigeria reported prevalence of $59.1 \%$ [9]. This difference may be associated with differences in socioculture and instrument used to assess for psychiatric morbidity. The subjects reported in that study were mainly of Yoruba ethnic group south west Nigeria which socioculturally differed from the Northwest Nigerians where the present study took place. In addition the instrument used had the advantage in discriminating against physical symptoms associated with chronic physical illness such as fatigue, which DSM IV they used could not.

The subjects were predominantly Hausa/Fulani ethnic group while the remaining subjects comprised of more than 10 different ethnic groups. We found variations in sociodemographic characteristics when the Hausa/Fulani ethnic group was compared with the other groups. The Hausa/Fulani group was similar to the other ethnic group with regard to age and gender. However more of the Hausa/Fulani were less educated and less likely to be married or employed.

Also subjects who were ethnic minority were found to have higher psychiatric morbidity than the Hausa/Fulani ethnic. In addition, age and marital status appeared to have effects on the prevalence across the ethnicity. This finding was consistent with previous study on ethnic density hypothesis which proposed that persons who live in neighbourhood with a greater proportion of residents of their own race or ethnicity have better mental health outcomes and lower levels of depression symptoms than persons who live in neighbourhood members with few people of their own race/ethnicity [16]. A review by
Shaw et al. [15] showed consistent finding of the protecttion of ethnic density on depression and anxiety. This protection was also extended to suicide and self harm. This finding has been supported by other previous studies. In one study, the smaller the ethnic group, the higher its hospitalization rate in comparison to both the rate of other residents in the same area and that of members of the same ethnic group living in areas where they constituted a numerical majority [14]. An extensive study which analyzed two cross sectional nationally representative surveys showed that nominally similar measures of ethnic density perform differently across health outcomes and measures of experienced racism in the two countries. In the US, increased Caribbean ethnic density was associated with improved health including mental health [26]. Other study which supported our finding was conducted among millennium group cohort which was a large prospective study of 18,819 infants and their 18,533 families born in 2000-2002 in the United Kingdom [27]. They found protective effect of ethnic density for limiting long term illness among Bangladeshi mothers at $5 \%-30 \%$ density and Pakistani mothers at all higher densities. However it was unrelated to infant outcomes.

The Hausa/Fulani ethnic group who were of age group 30 - 39 years had more definite anxiety than other age group among the ethnic group. However the other group who were of age group 30 - 39 years had more definite anxiety disorder than other age group among same ethnicity and among same age group of other ethnic group. However across gender, female patients reported anxiety disorder than the male subjects. Marriage appeared to have significant pathoplastic effects among the Hausa/ Fulani ethnic group.

The mechanism for this protection of ethnic density on mental health has been related to shared culture, social networks and social capital [27]. In addition, majority of the patient being Muslim have attribution hypothesis which states that everything has been preordained which may result in attenuation of emotion associated with chronic illness. Other hypothesis to support reasons why ethnic minority who were not presently living in own ethnic group include selective migration, genetic, neurodevelopmental, substance use and psycho social factors [28]. Migration: Odegaard [29] reported that individuals who were likely to migrate were due to selective migration and associated this with poor migration in Norway. However this was not supported by the findings of Selten et al. [30] which showed that Surinamese migrants were more likely than the Dutch had it been all the Surinamese were brought to Neitherlands. In addition, the initial negative symptoms which proceeded schizophrenia would reduce the likelihood for migration. Genetic: The study among the black Carribeans suggested that genetic played 
little role in the prevalence of psychiatric morbidity and associated the differences more to environment. Psychosocial factors such as unfamiliar culture and beliefs, different climate and environment, challenging interactions with government institutions and new language.

It is imperative to emphasize that the findings in this study should be interpreted with caution because of some limitation. For instance, being hospital based it is difficult to generalize. Also, sample size would appear to be small. In spite of these limitations, this study supported the protection role of ethnic density on psychiatric morbidity among patients with HIV infection suggesting that environmental manipulation could be of benefit in the management of the patient. Future study which these authors would be eager to carry out, involving larger sample size from the community is encouraged.

\section{ACKNOWLEDGEMENTS}

We acknowledge Drs. Gana, G.J., Ango, J.T., and Abdullahi, Z. of the department community medicine for assisting in the administration of the questionnaire.

\section{REFERENCES}

[1] Bing, E.G., et al. (2001) Psychiatric disorders and drug use among human immunodeficiency virus-infected adults in the United States. Archives of General Psychiatry, 58, 721-728. doi:10.1001/archpsyc.58.8.721

[2] Collins, P.Y., Holman, A.R., Freeman, M. and Patel, V. (2006) What is the relevance of mental health to HIV/ AIDS care and treatment programs in developing countries? A systematic review. AIDS, 20, 1571-1582. doi:10.1097/01.aids.0000238402.70379.d4

[3] Ciesla, J.A. and Roberts, J.E. (2001) Meta analysis of the relationship between HIV infection and risk for depressive disorders. American Journal of Psychiatry, 158, 725730. doi:10.1176/appi.ajp.158.5.725

[4] Bing, E.G., Burnam, M.A., Longshore, D., Fleishman, J.A., Sherbourne, C.D., London, A.S., Turner, B.J., Eggan Ferd, M.A., Beckman, R., Vitiello, B., Morton Sally, C., Maria, O., Bozzette, S.A., Ortiz-Barron, L. and Shapiro, M. (2001) Psychiatric disorders and drug use among human immunodeficiency virus-infected adults in the United States. Archives of General Psychiatry, 58, 721728. doi:10.1001/archpsyc.58.8.721

[5] Maj, M., et al. (1994) WHO neuropsychiatric AIDS study, cross-sectional phase I. Study design and psychiatric findings. Archives of General Psychiatry, 51, 39-49. doi:10.1001/archpsyc.1994.03950010039006

[6] Evans, S., Ferrando, S., Sewell, M., Goggin, K., Fishman, B. and Rabkin, J. (1998) Pain and depression in HIV illness. Psychosomatics, 39, 528-535. doi:10.1016/S0033-3182(98)71285-X

[7] Rabkin, J.G., Goetz, R.R., Remien, R.H., Williams, J.B., Todak, G. and Gorman, J.M. (1997) Stability of mood despite HIV illness progression in a group of homosexual men. American Journal of Psychiatry, 154, 1632-1633.

[8] Perkins, D.O., Stern, R.A., Golden, R.N., Murphy, C., Naftolowitz, D. and Evans, D.L. (1994) Mood disorders in HIV infection: Prevalence and risk factors in a nonepicenter of the AIDS Epidemic. American Journal of Psychiatry, 151, 233.

[9] Adewuya, A.O., Afolabi, M.O., Ola, B.A., Ogundele, O.A., Ajibare, A.O. and Oladipo, B.F. (2007) Psychiatric disorders among the HIV-positive population in Nigeria: A control study. Journal of Psychosomatic Research, 63, 203-206. doi:10.1016/j.jpsychores.2007.03.006

[10] Farinpour, R., et al. (2003) Psychosocial risk factors of HIV morbidity and mortality: Findings from the Multicenter AIDS Cohort Study (MACS). Journal of Clinical and Experimental Neuropsychology, 25, 654-670. doi:10.1076/jcen.25.5.654.14577

[11] Carrico, A.W., et al. (2011) Psychiatric risk factors for hiv disease progression: The role of inconsistent patterns of antiretroviral therapy utilization. Journal of Acquired Immune Deficiency Syndromes, 56, 146-150. doi:10.1097/QAI.0b013e318201df63

[12] Leserman, J., et al. (1995) Progression to AIDS: The effects of stress, depressive symptoms, and social support. Psychosomatic Medicine, 61, 397-406.

[13] Ironson, G., et al. (2005) Psychosocial factors predict CD4 and viral load change in men and women with human immunodeficiency virus in the era of highly active antiretroviral treatment. Psychosomatic Medicine, 67, 10131021. doi:10.1097/01.psy.0000188569.58998.c8

[14] Rabkin, J.G. (1979) Ethnic density and psychiatric hospitalization: Hazards of minority status. American Journal of Geriatric Psychiatry, 136, 1562-1566.

[15] Shaw, R., et al. A review of the impact of ethnic density on adult mental disorders. British Journal of Psychiatry, in Press.

[16] Halpern, D. and Nazroo, J. (2000) The ethnic density effect: Results from a national community survey of England and Wales. International Journal of Social Psychiatry, 46, 34-46. doi:10.1177/002076400004600105

[17] Yunusa, M.A., Obembe, A., Ibrahim, M.T.O. and Njoku, C.H. (2011) Prevalence and specific psychosocial factors associated with substance use and psychiatric morbidity among patients with HIV infection at Usmanu Danfodiyo University Teaching Hospital, Sokoto State, Nigeria. African Journals of Drugs and Alcohol Studies, 10, 11-16.

[18] Zigmond, A.S. and Snaith, R.P. (1983) The hospital anxiety and depression scale. Acta Psychiatrica Scandinavica, 67, 361-370.

[19] Abiodun, O.A. (1994) A validity study of the hospital anxiety and depression scale in general hospital units and a community sample in Nigeria. The British Journal of Psychiatry, 165, 669-672. doi:10.1192/bjp.165.5.669

[20] Fatoye, F.A., Mosaku, K.S., Komolafe, M. and Adewuya, A.O. (2006) Interictal anxiety and depression symptoms in Nigerians with epilepsy: A controlled study. Epilepsy \& Behavior, 9, 312-316.

[21] Savard, J., Laberge, B., Gauthier, J.G. and Bergeron, M.G. (1999) Screening clinical depression in HIV-seropositive 
patients using the hospital anxiety and depression scale. AIDS and Behavior, 3, 167-175. doi:10.1023/A:1025444225120

[22] Grant, B.F., Stinson, F.S., Dawson, D.A., Chou, S.P., Dufour, M.C., Compton, W., Pickering, R.P. and Kaplan, K.B.S. (2004) Prevalence and co-occurrence of substance use disorders and independent mood and anxiety disorders: Results from the national epidemiologic survey on alcohol and related conditions. Archives of General Psychiatry, 61, 807-816. doi:10.1001/archpsyc.61.8.807

[23] Katherine, F.M.M. and Sylvia, F.K. (2010) Prevalence of depression and anxiety disorders in HIV-positive outpatients in rural Tanzania. AIDS Care, 22, 415-419. doi:10.1080/09540120903253981

[24] Chandra, P.S., Ravi, V., Desai, A. and Subbakrishna, D.K. (1998) Anxiety and depression among hiv-infected heterosexuals-A report from India. Journal of Psychosomatic Research, 45, 401-409. doi:10.1016/S0022-3999(98)00028-2

[25] Kessler, R.C., Andrews, G., Colpe, L.J., Hiripi, E., Mroczek, D.K., Normand, S.L., Walters, E.E. and Zaslavsky, A.M. (2002) Short screening scales to monitor population prevalences and trends in non-specific psychological distress. Psychological Medicine, 32, 959-976.
doi:10.1017/S0033291702006074

[26] Bécares, L., Nazroo, J., Jackson, J. and Heuvelman, H. (2012) Ethnic density effects on health and experienced racism among Caribbean people in the US and England: A cross-national comparison. Social Science \& Medicine, 30, 1-9.

[27] Pickett, K., Shaw, R., Atkin, K., Kiernan, K. and Wilkinson, R. (2009) Ethnic density effects on maternal and infant health in the Millennium Cohort Study. Social Science \& Medicine, 69, 1476-1483. doi:10.1016/j.socscimed.2009.08.031

[28] Morgan, C., Charalambides, M., Hutchinson, G. and Murray, R.M. (2010) Migration, ethnicity, and psychosis: Toward a sociodevelopmental model. Schizophrenia Bulletin, 36, 655-664. doi:10.1093/schbul/sbq051

[29] Ødegaard, Ø. (1932) Emigration and insanity. Acta Psychiatrica et Neurologica Scandinavica. Supplementum, 4, 1-206.

[30] Selten, J.P., Slaets, J.P. and Kahn, R.S. (1997) Schizophrenia in Surinamese and Dutch Antillean immigrants to the Netherlands: Evidence of an increased incidence. Psychological Medicine, 27, 807-811. doi:10.1017/S0033291797005199 